\title{
Manufacturing Process of Ductile Pipe using Casting Technique
}

\author{
R.Manikandan, S.Rajesh, T.Nikhil Babu, P.Vaibhav, P.Pradeep kannan
}

\begin{abstract}
In this paper, study the behavior of bendable iron which is used to the manufacturing of ductile steel pipe. Bendable Iron offers higher elasticity than mellow steel and holds the intrinsic consumption opposition of cast iron because of its spheroidal graphite small scale structure. Thus this bendable iron is utilized in the production of channels by Srikalahasthi Pipes Limited. The state of graphite in the microstructure of the metal ranges from $100 \mathrm{~mm}$ to $1100 \mathrm{~mm}$ measurement for ductile and cast iron. Channels produced using Ductile Iron give considerable advantages as far as weight bearing capacity, sway opposition and ability to continue outer static/unique stacking. These channels have adaptable push-on joints which don't spill at a high or low weight, notwithstanding when avoided and are prominently known as 'Prepared to utilize' funnels, because of the simplicity of jointing these channels. In the assembling procedure of Ductile Iron funnels water is utilized for cooling frameworks in different areas. Keeping in perspective on generally water necessity and to lessen groundwater tapping, a 5 MLD sewerage treatment plant has been set up in 2011 at a capex of Rs 20crores which is adequate for procedure water prerequisite of the plant, which helped in sparing water amid the assembling procedure. The investigation of utilization of Ductile iron in the assembling of channels by Srikalahasthi Pipes Limited is giving beneficiaries in different segments as these are provided to different water sheets, civic enterprises, military specialist administrations, railroads, and contractual workers the nation over for their water foundation ventures.
\end{abstract}

Keywords:Ductile iron, Cast iron, Graphite, Pipes.

\section{INTRODUCTION}

$\mathrm{N}_{\text {ow }}$ as part of the expansion, SPL proposed to enhance the production capacity of Ductile Iron pipes, pig iron \& LAM Coke and power generation. In addition to the expansion, the company proposed to produce Ductile Iron fittings also.

Lanco Industries Ltd. is manufacturing a total of 4 products namely Pig iron, Slag cement, D.I. Spun pipes and LAM Coke. Major saleable products are D.I Spun pipes and

Revised Manuscript Received on July 22, 2019.

*corresponding author

Mr. R.Manikandan, Department of Mechanical Engineering, Kalasalingam Academy of Research and Education, Virudhunagar, Tamilnadu. Email: rmanikandan198@gmail.com

Dr.S.Rajesh*, Department of Mechanical Engineering, Kalasalingam Academy of Research and Education, Virudhunagar, Tamilnadu. Email: s.rajesh@klu.ac.in

Nikhil Babu, Department of Mechanical Engineering, Kalasalingam Academy of Research and Education, Virudhunagar,. Email: chathushvp7@gmail.com

P.Vaibhav, Department of Mechanical Engineering, Kalasalingam Academy of Research and Education, Virudhunagar,. Email: sibins29@gmail.com

P.Pradeep kannan M.Tech (ISE), Department of Mechanica Engineering, Kalasalingam Academy of Research and Education, Virudhunagar,Email: pradeepkannan45@gmail.com slag cement. Produced LAM Coke is used to produce Pig Iron and Molten Iron is used to produce the study of work done by M. Jagdishwar, Casing Feeder Design [1] D.I Spun pipes.

The die has been manufactured by using ductile iron because of the durability, strength and its hardness. The property of ductile iron is described [2]. The behavior of ductile iron pipe is described [3]. Many researched are done their research work in ductile iron materials by changing the ingredients along with ductile iron material and tests are carried out. The structural failure of the cast iron and ductile iron pipeline was done using fuzzy logic variables [4]. Engineering material is classified as a ductile and brittle material. In generally ductile material have five percent and above tensile strain before getting the fracture. The ductile iron pipe has high axial compressive load property and it is used as a coupling in two different pipelines [5]. The self-restrained ductile iron fitting was manufactured for the sealing and restraint system in the pipeline with the different application [6]. The ductile iron pipe is manufactured using a casting technique by changing the parameters like temperature, flow rate during pouring the molten metal into the mold and behavior is analyzed [7]. The ductile pipe performance is affected by changing the parameter like temperature, pressure and flow rate of the molten metal during the casting process. In this work, the ductile pipe manufacturing process using a casting technique is studied and compared with cast iron pipe.

\section{METHODOLOGY}

In industry, the steel pipe has been manufactured using different stages. The following steps are used to manufacture a steel pipe.

- Pig Iron (Material selection)

- Raw materials handling systems

- Batching and charging system

- Preparing of hot blast

- Blowing system.

In this industry, the ductile pipe is manufactured by using the following materials

- Recycled iron particle.

- Magnesium metal.

- Coke content.

- Mortar (Binding agent: Cement)

- Paint (Water based).

- A pure alloy of aluminum and zinc.

- Blue epoxy coatings 
The manufacturing process of the ductile pipe is given in Fig. 1

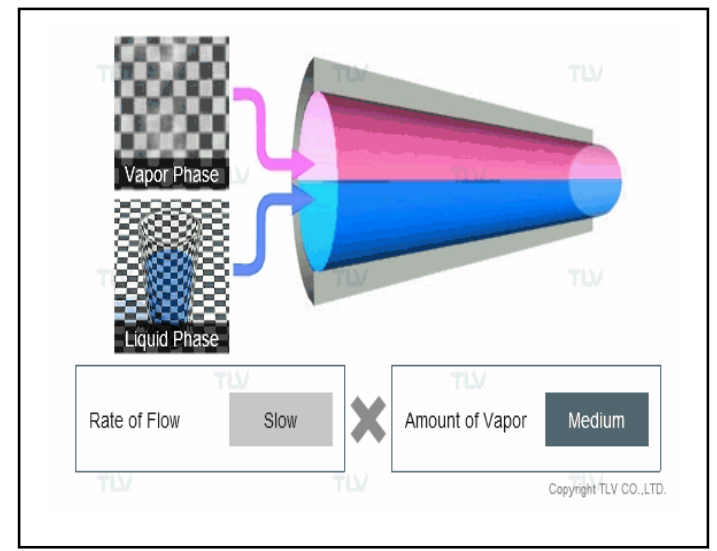

(a). Manufacturing steps

Recycled iron particle.

\section{Magnesium metal.}

\section{Coke content.}

\section{Cement Mortar}

\section{Paint}

Aluminum and zinc alloy

\section{Blue epoxy coatings}

(b). Ductile pipe ingredients

Fig.1. Manufacturing process and ingredients Of ductile pipe

After manufacturing of ductile pipe, the performance is analyzed by comparing the various properties like,

- Tensile strength

- Percentage of elongation

- Coefficient of thermal expansion

- Young's Modulus

- Hardness

- Density

- Bending strength

- The factor of safety.

The cement manufacturing process is a semi-dry Process. The raw meal is prepared by grinding and Mixing in the pre-worked proportions of main raw material like limestone with the additives (Iron ore, coke fines, clay, etc.).

Then the raw meal is burnt at a high temperature attained in the initial ignition system in a vertical shaft result in penultimate end product called clinker. A clinker is after cooling, along with slag and gypsum are fed into the cement mill and is ground to fineness to produce the finished product Portland Slag Cement.

Ductile Iron was used in the manufacture of pipes as it is resistant to corrosion as compared to that of cast iron. It has good strength and shape of the graphite in the microstructure of the metal is only varied from cast iron metal i.e., the size ranges from $100 \mathrm{~mm}$ to $1100 \mathrm{~mm}$ in diameter.

It provides superior tensile strength compared to mild steel and preserves the cast iron metal from intrinsic corrosion resistance, because of its spheroidal graphite microstructure. Ductile iron pipe offers significant merits in terms of bearing capacity, impact resistivity and has a good quality maintain to exterior loads i.e., for both static and dynamic loadings.

Pipes manufactured using Ductile Iron is known as "Ready to use pipes" due to their ease of joining.

These pipes are manufactured in such a way that they have zinc or epoxy coating with finishing layer of bituminous coating externally and internally cement mortar lining using large centrifugal force which provides excellent anti-corrosive properties.

\section{PROCESS OF LOW ASH METALLURGICAL COKE:}

The process of low ash metallurgical that can burn a high temperature of $1100^{\circ} \mathrm{C}$. The low ash system are two different types

1. Recovery type

2. Non-recovery type

We are only using Non-recovery type method various advantages by the product by a heating process that coke types will be listed below:

1. Less investment cost as no byproduct related equipment is required.

2. Low operation and maintenance cost.

3. Low conversion cost.

4. High coke.

5. The battery can be isolated and cooled down to repair at any time

6. without affecting the life of the risk

7. Environmental impact cleans fuel gas resulting and only emissions of burnt.

8. The non-recovery type will be operated by negative pressure.

9. By doing this type of manufacturing no pollution will be causes

10. resulting in clean stack discharges into the atmosphere

The photography of the company and casting production process is given Fig.2 


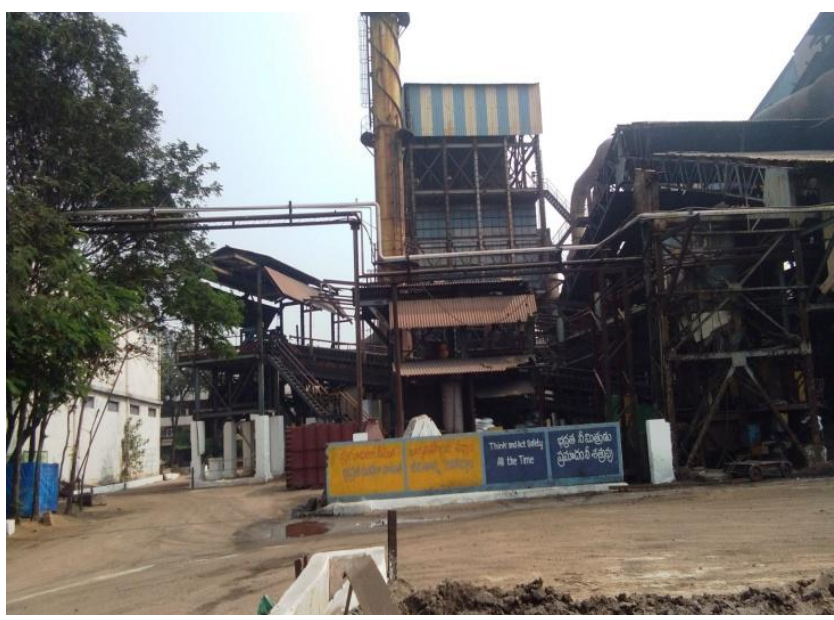

(a). Ductile pipe manufacturing company

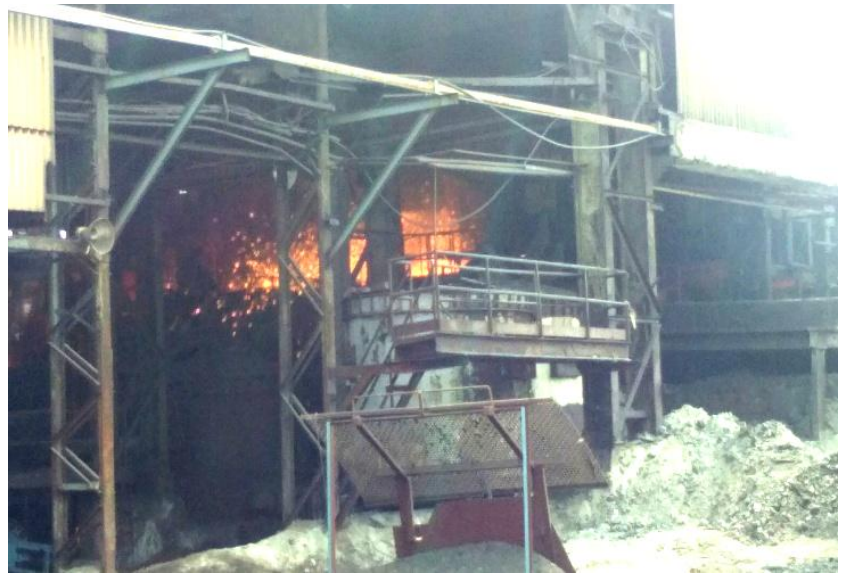

(b). During casting work in the company

Fig.2. Company outlook and casting work

\section{RESULT AND DISCUSSION}

It is observed from the studies of the property of materials used in pipeline, a ductile pipe is stronger and tougher than a cast iron pipe. Cast iron improves the attractive like machinability, corrosion resistivity. But the strength is less than the ductile pipe. The chemical properties of both ductile and cast iron pipe are the same. The spheroidal graphite form is used to increase the strength of the ductile pipe.

The property of the ductile pipe is compared with cast iron pipe. It is observed that the following property of the ductile pipe is more than a cast iron pipe. The Tensile strength of the ductile pipe is $420 \mathrm{Mpa}$ and it is more than the cast iron pipe. The percentage of elongation is higher for the ductile pipe. The elongation of the ductile pipe is $10 \%$. Coefficient of thermal expansion of the ductile pipe is more than cast iron pipe. Young's Modulus is also higher for ductile pipe compared to a cast iron pipe.

The hardness of the ductile pipe is $10 \mathrm{BHN}$ and it is lesser to cast iron pipe. Similarly, density, bending strength and factor of safety of the ductile pipe is more than cast iron pipe. The property of ductile and cast iron is given in Table.1
Table-I: A general property of ductile iron and cast iron pipe

\begin{tabular}{|l|l|l|}
\hline \multicolumn{1}{|c|}{ Property } & Ductile iron pipe & Cast iron pipe \\
\hline Tensile strength & $420 \mathrm{Mpa}$ & $414 \mathrm{MPa}$ \\
\hline Yield strength & $275 \mathrm{Mpa}$ & $276 \mathrm{MPa}$ \\
\hline Percentage of elongation & $10 \%$ & $18 \%$ \\
\hline Impact strength & 1.7 to $5 \%$ & 1.7 to $5 \%$ \\
\hline
\end{tabular}

We got practiced in Srikalahasthi Pipes Limited about the machines that can be operated by an automated machine system. The manpower is needed to operate that machines that can be analyzed by an engineer, we are operating the pressure wall ON and OFF operating system through which the ductile pipes are molded in required shape and diameter. These pipes are molded in required shape through automated machines but the required diameter cannot be coded automatically. So that to maintain a proper diameter of pipes manpower is needed. Required diameter is arranged by using the switches which are allotted in machines through which the diameter of pipes is set.

Many waste steel materials and waste cars are burned to melt the material to use it. This melted material is molded into required shapes; the especially cylindrical shape is more frequently molded as this shape is mostly used for various purposes.

By working with these machines we got some knowledge how the materials are collected, stored, melted and molded into different shapes of required diameter for various mankind purposes especially in water supply boards in municipal corporations, military engineer services, railways and contractors across the country for their water infrastructure projects.

\section{CONCLUSION}

From the above observation, the ductile steel pipe is improving the ductility, durability of the pipe; avoid the damage during handling and storage condition. It is also recyclable material through that the generation of waste also reduced. So, Many Industries preferring manufacturing of ductile steel pipe here we have done in manufacturing process of steel pipes in that can be operated by automatic machines and by the casting of need a ductile shape can be changed by their given shapes it can be molded by the top of the different shape of head to the pipe it can be a curved shape it doesn't changes the to hold the grip to ground and it may change to rectangle shape it behold very nicely to stick the ground are any other area. 


\section{REFERENCES}

1. M.Jagdishwar,'Casing Feeder Design

Optimization based on feed path and temperature analysis," 2012.

2. Charles W. Mooney, Jr. Dies, "The best of Ductile

iron news\|," IL, 2001, pp. 60016-8399

3. Guss Rohrsysteme, Griesheim, "Ductile iron pipe

System,"the European association for Ductile iron pipe systems, 2004

4. H.Najjaran, R.Sadiq \&B.Rajani,'Fuzzy

expert system to assess corrosion of cast/ductile iron pipes from backfill properties," Computer-Aided Civil and Infrastructure Engineering, 21(1), 2006, pp. 67-77.

5. W. T.Adams Jr, U.S. Patent No. 5,480,196, "Washington, DC:

"U.S. Patent and Trademark Office," 2010

6. J.Jones, G.Darce, R.Chinchilla, \&B.G.Corbett Jr

U.S. Patent No. 7,815,225. Washington, DC: U.S. Patent and Trademark Office, 2010

7. E.F.Wagner, "Autogenous Healing of Cracks in

Cement Mortar Linings for Gray Iron and Ductile Iron Water Pipe, "Journal American Water Works Association,66(6), 2012, pp.358-360.

\section{AUTHORS PROFILE}

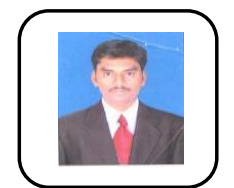

R.Manikandan obtained his B.E (MECH) in 2009 from the P.S.R Engineering College, Sivakasi, Tamilnadu, India. He completed his M.Tech (Industrial Safety Engineering) in 2014 at Mepco Schlenk Engineering College, Tamilnadu, India. Currently, he is working as a Assistant Professor in the Department of Mechanical Engineering, Kalasalingam Academy of Research and Education, Krishnankoil, Tamilnadu, India. His research interests include investigation of fireworks accidents and exposure of various experimental setup like frition, impact sensivity test, Noise level test and thermal analysis test.

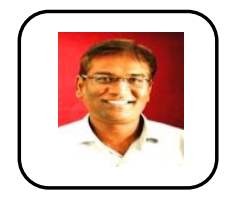

I have completed in B. E in Mechanical Engineering and M.E. (CAD) from Alagappa Chettiar Governmen College of Engineering and Technology, Karaikudi, $\mathrm{Ph} . \mathrm{D}$ (Machining of Metal of Matrix Composites) from Kalasalingam Academy of Research and Education, Krishnankoil in the year 2014, and thesis highly recommended by both the examiners. In the year 2018, I have received DST - AMT project for the worth of Rs 25, 72, 400 and completed one IEDC project for the worth of Rs 1, 00,000. I have published more than 25 journal papers (impact factor and Scopus cited) and more than 40 international conference papers.

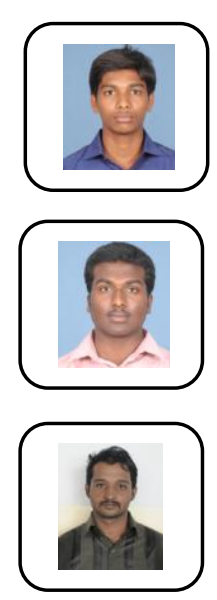

T.Nikhil Babuis a final year student, Department of Mechanical Engineering, Kalasalingam Academy of Research and Education, Krishnankoil, Tamilnadu, India

P.Vaibhav is a final year student, Department of Mechanical Engineering, Kalasalingam Academy of Research and Education, Krishnankoil, Tamilnadu, India.

P.Pradeep kannanis a second year M.Tech Industrial Safety Engineering student, Department of Mechanical Engineering, Kalasalingam Academy of Research and Education, Krishnankoil, Tamilnadu, India 